\title{
PERTAHANKAN DIVERSIFIKASI ASAL PANGAN POKOK SEBAGAI STRATEGI PENCAPAIAN KETAHANAN DAN PERTAHANAN PANGAN NASIONAL
}

\section{MAINTAIN DIVERSIFICATION OF FOOD ORIGINS AS A STRATEGY TO ACHIEVE RESILIENCE AND NATIONAL FOOD DEFENSE}

\author{
Roosganda Elizabeth \\ BRIN/Pusat Analisis Sosial Ekonomi dan Kebijakan Pertanian \\ Email: roosimanru@yahoo.com \\ (Diterima 07-01-2022; Disetujui 27-01-2022)
}

\begin{abstract}
ABSTRAK
Kedaulatan, ketahanan dan pertahanan pangan rumah tangga diartikan sebagai seluruh penduduk memperoleh dan mampu mengkonsumsi pangan yang cukup dalam kuantitas, kualitas, bergizi dan terjangkau. Program kebijakan pengentasan kemiskinan dan kelaparan terkait erat dengan terpenuhinya ekonomi dan kebutuhan pangan masyarakat. Produksi pangan usahatani dan peternakan bertujuan mencukupi kebutuhan masyarakat dan sebagai sumber penghasilan pelaku yang terlibat. Di hilirnya dipengaruhi ketersediaan pangan yang aman, bergizi dan terjangkau yang disertai kemampuan masyarakat memperoleh pendapatan. Kebijakan tersebut secara nasional, mempengaruhi kedaulatan, ketahanan dan pertahanan pangan serta keberlanjutan pembangunan pertanian dalam jangkauan lebih luas, bukan sekedar produksi dan produktivitas semata. Dengan deskriptif kualitatif, tulisan ini mengemukakan pemberdayaan SDM dan kelembagaan pertanian sebagai strategi pencapaian dan peningkatan kedaulatan, ketahanan dan pertahanan pangan terkait aspek ketersediaan serta diversifikasinya. Adalah kenyataan bahwa kemiskinan dan kelaparan terkait erat dengan kedaulatan, ketahanan dan pertahanan pangan merupakan agenda yang tidak pernah berakhir (the unfinished agenda). Mengingat potensi sumberdaya alam, tenaga kerja, lingkungan wilayah pedesaan sangat mendukung pengembangan pertanian dan peternakan dengan mengintegrasikan sistem tanaman-ternak terpadu baik organik maupun spesifik lokal. Kedaulatan, ketahanan dan pertahanan pangan dapat terwujud melalui fungsi infrastruktur penyediaan, distribusi dan konsumsi pangan, oleh pelaku usaha produksi (produsen hingga pasca panen), distribusi dan jasa serta mengelola diversifikasi pangan dan gizi. Pentingnya kecukupan pangan mencerminkan capaian program kebijakan pembangunan nasional, meski keberlanjutannya nantinya masih suatu keniscayaan.
\end{abstract}

Kata Kunci: strategi nasional, kedaulatan, ketahanan dan pertahanan pangan, solusi pengentasan kemiskinan

\begin{abstract}
Sovereignty, security and household food defense are defined as the entire population obtaining and being able to consume sufficient food in quantity, quality, nutritious and affordable. The poverty and hunger alleviation policy program is closely related to the fulfillment of the economy and the food needs of the community. Farming and livestock food production aims to meet the needs of the community and as a source of income for the actors involved. Downstream, it is influenced by the availability of safe, nutritious and affordable food along with the community's ability to earn income. The policy is national, affecting sovereignty, food security and defense as well as the sustainability of agricultural development in a wider range, not just production and productivity. With a qualitative descriptive, this paper proposes the empowerment of human resources and agricultural institutions as a strategy for achieving and increasing food sovereignty, security and defense related to aspects of availability and diversification. It is a fact that poverty and hunger are closely related to sovereignty, food security and defense, which is an unfinished
\end{abstract}




\section{PERTAHANKAN DIVERSIFIKASI ASAL PANGAN POKOK SEBAGAI STRATEGI \\ PENCAPAIAN KETAHANAN DAN PERTAHANAN PANGAN NASIONAL \\ Roosganda Elizabeth}

agenda. Considering the potential of natural resources, labor, and the environment in rural areas, it is very supportive of the development of agriculture and animal husbandry by integrating an integrated crop-livestock system, both organic and locally specific. Sovereignty, food security and defense can be realized through the function of infrastructure for food supply, distribution and consumption, by business actors in production (producers to post-harvest), distribution and services as well as managing food and nutrition diversification. The importance of adequate food reflects the achievements of the national development policy program, although its sustainability will still be a necessity.

Keywords: national strategy, sovereignty, food security and defense, poverty alleviation solutions

\section{PENDAHULUAN}

Liberalisasi perdagangan dan sektor pertanian Indonesia belum sepenuhnya mampu membuka lapangan kerja dan usaha untuk mendorong minat berusaha di bidang pangan. Salah satu implikasinya terkait dengan kondisi riil angka penggangguran relatif tidak berkurang, terutama di masa pandemi Covid-19 sekarang ini yang tak kunjung berakhir.

Diimplementasikannya beberapa program utama kebijakan nasional meningkatkan produktivitas pertanian unggulan, mutu, jumlah dan diversifikasi, serta mengatasi ketimpangan dan kekurangan produksi adalah untuk membangun ketahanan pangan nasional. Tulisan ini bertujuan mengemukakan pemberdayaan SDM dan kelembagaan pertanian sebagai strategi pencapaian dan peningkatan kedaulatan, ketahanan dan pertahanan pangan terkait aspek ketersediaan serta diversifikasinya. Dengan deskriptif kualitatif, yang diperkaya dengan review berbagai kajian dan literature terkait lainnya. Ketahanan pangan menjamin kehidupan dan kesehatan tubuh manusia sangat urgen untuk segera diimplementasikan dengan jelas arahan pelaksanaannya. Ketersediaan pangan pertanian dan peternakan selayaknya dapat mencukupi dan mampu dikonsumsi dalam jumlah, mutu dan gizi yang terjangkau. Semakin kompleksnya masalah ketersediaan dan pemenuhan pangan bergizi diatasi dengan diversifikasi pangan, sebagai terobosan perbaikan pangan dan gizi masyarakat berpenghasilan rendah yang dapat dikaji dari indikator makro kesejahteraan rakyat. Oleh karena itu, diperlukan strategi penyusunan program kebijakan lebih efisien dan efektif serta penajaman aspek dan prioritas pembangunan pertanian peternakan.

\section{Program Diversifikasi Pangan: Pemenuhan dan Peningkatan Pangan- Keragamannya}

Tolok ukur berhasil tidaknya pelaksanaan program utama pembangunan adalah ketahanan pangan sehingga penentu kebijakan peningkatan 
ketahanan pangan pada posisi utama dan strategis dalam kerangka pembangunan nasional (Elizabeth. 2018; 2021). Tujuan program pangan adalah: untuk meningkatkan ketersediaan pangan berkelanjutan, mengembangkan diversifikasi pangan dengan lembagalembaga terkait pangan. Keberhasilan usaha di bidang produk asal pertanian dan peternakan, mengembangkan kelembagaan pangan yang efektif dan akurat, serta mengembangkan usaha pengelolaan asal pangan salah satunya adalah dari hasil produksi pertanian dan produk peternakan. Dibutuhkan keberpihakan dan pendampingan sebagai dukungan pemerintah dan instansi terkait menjadi penentu keberhasilan program diversifikasi pangan, kebijakan/peraturan, perencanaan, pelaksanaan evaluasi monitoring.

Pelaksanaanprogrampeningkatan

ketahanan pangan dapat dioperasikan dengan menggunakan beberapa bentuk kegiatan: (i) Perluasan areal tanam (ekstensifikasi) yang dilaksanakan dalam bentuk pengairan serta perluasan lahan dan peningkatan indeks pertanaman melalui percepatan pengolahan tanah, pemupukan dengan gbahan organi serta penggarapan lahan tidur dan terlantar; (ii) Penanaman lahan kosong perkebunan yang tidak terurus, agar dapat menghasilkan baik hasil pertanian maupun dari hijauan untuk kepentingan pakan ternak; (iii) RehabilitasI dan konservasi lahan dan air tanah dan air tanah, dilaksanakan dalam bentuk upaya perbaikan kualitas lahan kritis/marginal dan pembuatan serta embung dan rorak/jebakan air; (iv) Peningkatan mutu intensifikasi yang dilaksanakan dalam bentuk usaha peningkatan produktivitas melalui upaya penerapan teknologi tepat guna, peningkatan pengetahuan, keterampilan petani dalam penerapan teknologi spesifik lokasi; Memperkenalkan sebagai pengganti makan sehari-hari adalah hasil dari pertanian umbi-umbian sebagai bahan karbohidrat sebagai bahan konsumsi bagi kebutuhan tubuh manusia; (vi)Pengamanan produksi melalui penggunaan teknologi panen yang tepat, pengendalian OPT dan bantuan saprodi pada lahan mengalami puso; (vii) Penggunaan bibit unggul dan aspek penunjang keberhasilan usaha ternak (ruminansia besar, kecil), dan unggas (ayam kampung, ayam potong).

Program diversifikasi pangan perlu disiapkan dan dilaksanakan dengan perencanaan secara holistik dan terintegrasi, mulai dari hulu (budidaya) 


\section{PERTAHANKAN DIVERSIFIKASI ASAL PANGAN POKOK SEBAGAI STRATEGI \\ PENCAPAIAN KETAHANAN DAN PERTAHANAN PANGAN NASIONAL \\ Roosganda Elizabeth}

hingga hilirnya (pascapanen), serta dengan target capaian yang jelas dan terarah, disertai monev dan pendampingan yang berpihak dan berkesinambungan. Proses pengolahan produk pangan lokal perlu dilakukan dengan memanfaatkan proses/ teknologi tepat guna, sehingga diperoleh produk pangan yang standar, serta memenuhi kriteria konsumsi makanan seimbang dan aman. Disisi lain, dibutuhkan dukungan industri pengolahan berteknologi tepatguna selalu inovatif dalam upaya meningkatkan nilai tambah, daya saing dan pengembangan produk olahan. sebagainya untuk dikembangkan menjadi produk olahan (mie, biscuit, roti, snack, dsb). Produk antara dari komoditas hasil pangan lokal sangat direkomendasikan, sedemikian produk antara ini dapat disimpan lebih lama dan dapat diolah lebih lanjut menjadi pangan siap saji. Pendukung keberhasilan diversifikasi pangan, perlu diperhatikan tampilan penyajian siap saji menjadi penentu kualitas, kuantitas dan penampilan makanan konsumsi. Diversifikasi pangan juga direkomendasikan bahan pangan substitusi impor. Mocaf, terigu, panir, rice flour disubstitusi dengan memanfaatkan produk lokal (pati singkong, sagu, jagung, beras, gandum, dll). Sasaran yang dapat dicapai dari program pangan dengan tercapainya ketersediaan pangan ditingkat regional dan masyarakat yang cukup serta mendorong partisipasi masyarakat dalam mewujudkan ketahanan pangan serta meningkatnya keanekaragaman konumsi pangan di masyarakat dan menurutnya ketergantungan pada asal pangan pokok beras melalui pengalihan konsumsi non beras.

Beberapa faktor utama dan upaya yang perlu diantisipasi diversifikasi ranah usaha hasil pertanian peternakan, seperti: (i) Ketersediaan input untuk komoditas yang baik untuk dijadikan peluang bisnis, atau usaha dimana produksen dapat mengetahui banyaknya sumber daya pertanian, yang bervariasi jenis produk serta mutu komoditas sangat memungkinkan diperoleh, dan didukung oleh sistem distribusi yang efektif dan efisien serta kena sasaran; (ii) Sarana dan prasarana pendukung seperti infrastruktur, transportasi, komunikasi, dan lain-lain dan tersedianya pangan yang sebagian besar merupakan produksi sendiri baik dari hasil pertanian maupun dari hasil peternakan serta stabilitas dan kontinuitas ketersediaan pangan yang sangat cukup baik dan terjamin, aksesibilitas dan keterjangkauan pangan 
secara memadai dan kualitas konsumsi yang sehat dan aman di konsumsi oleh kalangan masyarakat pada umumnya; (iii) Kebijakan pemerintah yang mendukung pengembangan usaha, baik adanya kebijakan fiskal dan moneter serta peraturan dan perundang-undangan untuk mengatur hasil hasil produksi pertanian dan peternakan sehingga dalam perjalanannya lancar; (iv) Lembagalembaga pendukung salah satunya koperasi, perbankan dan lembaga pembiayaan lainnya yang mampu memfasilitasi pelayanan dari berbagai macam produk dengan spesifikasi pelayanan yang dibutuhkan untuk masing-masing unit atau kelompok usaha atau agribisnis.

\section{Sumber dan Diversifikasi Ekonomi Hasil Produksi Pertanian}

Diversifikasi terkait erat dan timbal balik dengan keberagaman produk hasil atau jasa yang berbeda-beda dalam suatu penawaran bisnis. Diversifikasi membutuhkan kesigapan dan keterampilan dalam mengadaptasi dan memodifikasi kegiatan bisnis lebih dari satu usaha pengolah. Melakukan diversifikasi, berarti bergerak kepada beberapa lini produk dan diversifikasi merupakan satu cara untuk mengeliminasi dampak negatif atau resiko yang dihadapi oleh pengusaha. Perubahan lingkungan dan teknologi agribisnis menjadi suatu penyebab meningkatnya tekanan untuk berspesialisasi untuk mencapai economic of scale atau skala ekonomis dimana juga tanggapan dari keinginan pasar untuk menghasilkan produk yang memenuhi keinginan konsumen, baik itu dalam hal mutu dan harga. Dengan adanya diversifikasi, memungkinkan para pengusaha terutama agribisnis dapat meminimalisir dampak kerugian, dimana kerugian satu lini produk dapat ditutupi lini produk lainnya. Namun diversifikasi dalam agribisnis menjadi tidak populer, karena adanya tekanan efisiensi, sehingga spesialisasi pada satu lini produk yang memiliki keunggulan komparatif dan keunggulan kompetitif menjadi suatu pilihan (Fauzi. 2014; Yasa. 2016. Menkoekuin. 2016. Penganekaragaman hasil produk pertanian dan peternakan (bidang usaha/agribisnis) atau lokasi perusahaan yang dilakukan suatu perusahaan untuk memaksimalkan keuntungan sehingga arus kas perusahaan dapat lebih stabil, yang dilakukan oleh perusahaan untuk mengatasi krisis ekonomi, sehingga apabila suatu perusahaan mengalami kemerosotan pendapatan di salah satu produk lain 


\section{PERTAHANKAN DIVERSIFIKASI ASAL PANGAN POKOK SEBAGAI STRATEGI \\ PENCAPAIAN KETAHANAN DAN PERTAHANAN PANGAN NASIONAL \\ Roosganda Elizabeth}

mendapatkan kelebihan pendapatan, sehingga kekurangan yang terjadi bisa tertutupi.

Penting dan kian mahalnya kesehatan dan meningkatnya perolehan pendapatan di beberapa golongan masyarakat membuat semakin giat merintis konsumsi pangan sehat, aman, bermutu dan bergizi, yang mayoritas menggunakan sarana produksi berbasis bahan yang aman dan minimalisir kimia. Tingkat kesadaran konsumen terhadap produk sehat dan aman relatif masih rendah, disebabkan terbatasnya edukasi dan sosialisasinya ke konsumen, menyebabkan masih relatif rendahnya pembelian pangan aman, sehat, berkualitas dan bergizi. Akses dan keterjangkauan masih menjadi kendala utama konsumen mendapatkan pangan sehat dan aman tersebut. Minimnya informasi, tempat penjualan, harga terjangkau menjadi masalah. Konsumen membeli pangan aman dan sehat di ritel modern, online market, tersegmentasi pada berpenghasilan menengah atas. Prospek peningkatan konsumsi suatu produk dipengaruhi oleh teori perilaku terencana, sikap, norma subyektif, persepsi kontrol perilaku, niat dan perilaku. Program untuk meningkatkan ketahanan pangan dalam mengoperasikan pembangunan dalam rangka mengembangkan sistem ketahanan pangan baik di tingkat nasional maupun di tingkat masyarakat.

Pangan dalam arti luas yang dapat mencukupi pangan baik yang berasal dari hasil produksi tanaman pangan, peternakan dan perikanan, gunanya untuk dapat untuk memenuhi kebutuhan atas karbohidrat bagi masyarakat. Ketahanan pangan diartikan dapat terpenuhinya kebutuhan asal pangan dengan ketersediaan yang cukup tersedia seriap saat disemua daerah dan mudah diperoleh aman dikonsumsi, halal dengan harga yang terjangkau. Hal ini dapat diwujudkan dengan bekerjasama dengan subsistem distribusi dan subsistem konsumsi. Terciptanya nilai tambah dan lapangan kerja, terserapnya sejumlah tenaga kerja, peningkatan pengetahuan dan ketrampilan teknologi pengolahan SDM, terbukanya peluang usaha pengolahan produk pertanian, meningkatnya akses informasi luar desa, mampu memotori industrialisasi pedesaan, meningkatnya pertumbuhan ekonomi, peningkatan pembagian dan penyebaran pendapatan, peningkatan penerimaan devisa, penghela pembangunan pertanian serta perbaikan kelembagaan pasar sehingga mampu 
meraih dan memperluas pemasaran merupakan strategi pengembangan agroindustri.

\section{Pertahankan Diversifikasi Asal Pangan Pokok}

Diversifikasi pangan dimaksudkan untuk memperbaiki pola konsumsi masyarakat supaya lebih beragam jenis, mutu dan gizi yang baik. Meski nyatanya beberapa daerah di Indonesia mengkonsumsi jagung, sagu, singkong, atau ubi rambat sebagai bahan pangan pokok (Rahmat. 2012. Kusuwardhani. 2012. Pribadu. 2014; Sulystyana. 2014). Namun kenyataannya sekarang, di Maluku yang semula mengkonsumsi sagu sebagai bahan pangan pokoknya, Dalam upaya mempertahankan pangan pokok daerah seperti tiwul dari singkong masih dipersepsikan minor karena identik dengan orang tidak mampu. Demikian juga halnya dengan pangan pokok kentang, dan nasi jagung (Madura, NTB, NTT, Papua). Makanan pokok bukan beras tersebut, semakin lama semakin ditinggalkan karena iming-iming lifestyle dengan lebih bergengsinya makanan pokok beras (Yusalina. 2011; Hadi. 2014. Widjaya. 2014. Menkoekuin. 2014). Padahal pangan pokok bukan beras, dari sisi kesehatan dan keseimbangan pemasukan karbohidrat yang dapat dicerna dengan baik oleh organ pencernaan dan sesuai kebutuhan tubuh untuk beraktivitas sehari-harinya. Makanan pokok berbasisi sagu (papeda, bagea, roti, bubur, dsb) masih terkendala dalam melakukan diversifikasi mengingat pohon sagu semakin lama semakin hilang/habis karena tidak menanam kembali bibit pohon sagu penggantinya (Tjeppy. 2011; Harjono. 2012; YLKI. 2012). Bahan pangan berbasis sagu adalah hasil ekstraksi bagian inti batang pohon sagu. Di tepi-tepi pantai Sumatera Timur, Kalimantan, Sulawesi, dan Irian Jaya serta kepulauan di sekitar Maluku dan kepulauan Mentawai terdapat hutan sagu yang pada dasarnya tumbuh liar secara alamiah. Sebagian masyarakat di wilayah-wilayah tersebut memanfaatkan pohon sagu untuk diambil patinya (amylum) yang terdapat di bagian tengah batangnya. Satu pohon sagu dapat menyediakan bahan tepung yang cukup untuk menyediakan bahan makanan pokok bagi suatu keluarga yang terdiri atas lima orang selama satu bulan.

Di Malaysia, pohon sagu sudah dibudidayakan dalam bentuk perkebunan dan pati (tepung sagu) yang didapat merupakan komoditas perdagangan. Di Indonesia Timur, tepung sagu diproduksi dengan cara tradisional untuk konsumsi 


\section{PERTAHANKAN DIVERSIFIKASI ASAL PANGAN POKOK SEBAGAI STRATEGI \\ PENCAPAIAN KETAHANAN DAN PERTAHANAN PANGAN NASIONAL \\ Roosganda Elizabeth}

rumahtangga dan sebagian untuk diperdagangkan. Bentuk dalam perdagangan berupa balok-balok kecil sagu kering atau diolah sebagai butirbutir yang disebut sagu mutiara. Di kepulauan Mentawai, sagu hanya dipergunakan untuk konsumsi keluarga sendiri dan karena jumlah penduduk masih sangat sedikit, sedangkan penebangan pohon sagu dilakukan secara tradisional dan tidak berlebihan. Satu rumpun sagu setiap dua tahun memberikan satu pohon sagu yang matang untuk ditebang dan diambil sagunya. Sejak umur sekitar 8 tahun kadar sagu di dalam batang pohon sagu bertambah terus dan mencapai puncaknya pada saat pohon itu mulai berbunga. Pada saat inilah pohon harus ditebang dan diambil patinya/sagunya. Pada salah satu sisi batang pohon sagu dikupas kulitnya dan hati batang yang cukup lunak itu dikeluarkan dengan memukul-mukul atau dengan alat pemarut sederhana. Batang sagu yang telah diambil hatinya dipasang pada tonggak-tonggak digunakan untuk menampung hasil hati pohon sagu yang dihancurkan dengan air, seperti susu putih mengalir pada ujung bawah dan ditampung dalam bejana perahu terbuat dari pohon sagu juga, dibiarkan mengendap menjadi lapisan pati di dasar bejana penampung untuk dikeringkan dan diolah menjadi tepung sagu.

Di daerah kepulauan Mentawai dan Irian Jaya, pengolahan sagu di rumahtangga untuk dikonsumsi masih primitif dalam bentuk adonan dibakar di api terbuka atau dimasukkan ke dalam abu panas. Di Maluku dan Sulawesi Utara bahan baku sagu memasaknya sudah lebih maju dalam bentuk masakan yang disebut Papeda atau berbagai jenis kue kering (bagea). Balok-balok kecil sagu kering dapat juga dicelupkan ke dalam kuah dan langsung disantap. Papeda adalah sejenis makanan berkuah serupa bubur, ditambahkan sayur dan potongan-potongan daging atau ikan. Dalam bentuk papeda ini, susunan hidangan mengandung cukup berbagai zat gizi yang diperlukan tubuh, sehingga sanggup memberikan kesehatan dan daya kerja yang memadai. Hidangan dengan dasar bahan makanan pokok sagu pada umumnya disuplementasi dengan sayur dan daging atau ikan yang cukup, sehingga tidak kalah dengan hidangan berdasarkan bahan makanan pokok beras/nasi. Nilai lebih pohon sagu, antara lain: pemeliharaan sangat sedikit menggunakan waktu dan tenaga, tidak perlu menyiangi rumput secara intensif, sampai sekarang tidak ada masalah hama, 
pertumbuhan dan perkembangbiakan terjadi mudah secara alamiah, hampir segala bagian pohon dapat dimanfaatkan untuk keperluan penghidupan, dan limbah ampas sagu dapat dipergunakan untuk campuran pakan hewan (Astuti. 2012; dalam: Elizabeth. 2019).

\section{PENCAPAIAN KETAHANAN DAN PERTAHANAN PANGAN NASIONAL}

Diversifikasi pangan merupakan konsep yang terpadu dan memadukan berbagai perangkat kebijakan, dan tidak berdiri sendiri. Diversifikasi pangan terkait erat dengan diversifikasi tanaman pangan, dimana diversifikasi pangan melihat dari sisi konsumsi sedang diversifikasi tanaman pangan melihat dari sisi produksi. Dengan demikian, program diversifikasi telah mengubah peranan komoditas non pangan beras terhadap perekonomian nasional melalui dua sisi, yaitu: produksi sekaligus konsumsi. Ketidakseimbangan antara pola konsumsi pangan dengan ketersediaan (produksi) pangan di masyarakat merupakan permasalahan utama diversifikasi pangan. Terjadinya perubahan penawaran dan permintaan tanaman pangan non beras merupakan aspek yang harus dipertimbangkan dalam penyusunan dan pembuatan kebijakan program diversifikasi yaitu: (1) implikasi terhadap diversifikasi produksi tanaman pangan (diversifikasi pertanian); dan implikasi terhadap diversifikasi konsumsi tanaman pangan (diversifikasi pangan).

Pada ranah nasional, kedaulatan pangan diartikan sebagai kemampuan dalam negeri suatu bangsa atau negara untuk memperoleh pangan yang cukup, mutu yang layak dan sehat (higienis), serta aman. Keterjaminan tersebut berbasiskan optimalisasi pemanfaatan dan keragaman sumberdaya lokal, yang tercermin oleh indikator secara mikro dan makro. Indikator secara mikro adalah keterjangkauan pangan secara langsung oleh masyarakat dan rumah tangga, sedangkan secara makro adalah ketersediaan dan kontiniutas pangan, terdistribusi dan terkonsumsi dengan kualitas gizi yang berimbang, baik pada tingkat wilayah maupun pada tingkat nasional.

Beralihnya konsumsi pangan pokok bukan beras cenderung $70-80 \%$ bahkan lebih $90 \%$ telah beralih menjadi panganberas, bahkan partisipasi pangannya menyamai Sumatera Utara dan Sumatera Barat. Program kebijakan pemerintah dilaksanakan cenderung hanya seputar padi saja. Terjebaknya dengan hanya memprioritaskan kebijakan produksi ataupun kebijakan harga yang 


\section{PERTAHANKAN DIVERSIFIKASI ASAL PANGAN POKOK SEBAGAI STRATEGI \\ PENCAPAIAN KETAHANAN DAN PERTAHANAN PANGAN NASIONAL \\ Roosganda Elizabeth}

diutamakan untuk meningkatkan produksi padi. Kebijakan tersebut dilaksanakan melalui program pro rakyat, yang dikemas dalam berbagai progam, salah satunya adalah Program Peningkatan Beras Nasional (P2BN). Untuk memantapkan produksi padi dan diversifikasi pangan, diperlukan strategi melalui pembenahan kelembagaan pangan, diantaranya adalah kelembagaan kelompok tani dan KUD. Hal tersebut dilakukan karena kelompok tani dapat berperan di sektor produksi, distribusi, pengolahan dan konsumsi. Sedangkan KUD sebagai unsur pendukung dan sebagai sarana penyediaan kredit, sarana produksi, serta dapat bertindak sebagai pengolah dan pemasaran hasil (Elizabeth. 2015). Dengan demikian, menurut, pendukung utama terlaksananya strategi tersebut dalam upaya pencapaian ketahanan pangan, kedaulatan pangan, serta diversifikasi pangan sangat diperlukan ketersediaan perangkat kebijakan yang memadai, teknologi dan informasi yang dibutuhkan (Elizabeth. 2018; 2017), serta berfungsinya lembaga pendukung lainnya seperti: penyuluhan, pemasaran, dan sistem pendekatan instansi terkait (Elizabeth. 2014; 2019).

Dukungan kebijakan pemerintah yang lebih fokus dan berpihak, serta keberpihakan melalui pelatihan dan pendampingan. Kebijakan diperlukan untuk memberi ruang yang lebih besar, karena diperlukan strategi sebagai upaya pemantapan ketahanan pangan yang berkaitan erat dengan upaya peningkatan pendapatan skala rumah tangga. Tingkat pendapatan rumah tangga dapat mencerminkan dan menjadi salah satu faktor kunci bagi rumah tangga untuk menjadi salah satu ukuran kemampuan dalam mengakses konsumsi pangan yang dibutuhkan beserta keragamannya. Faktor lain yang tidak kalah pentingnya adalah pemasaran, sebagai salah satu subsistem aktivitas bisnis dari produk hasil agroindustri, diarahkan pada perbaikan mekanisme penentuan harga yang layak bagi produsen dan pelaku pemasaran. Pengkajian pemasaran dapat dilakukan melalui berbagai pendekatan yang umum berlaku dalam aktivitas agribisnis, terutama pemasaran hasil produk agroindustri (Elizabeth. 2017a). Lembaga di pedesaan lahir untuk memenuhi kebutuhan sosial masyarakatnya (BBIA. 2014; dalam: 2015; 2016; 2017; 2018). Sifatnya tidak linier, namun cenderung merupakan kebutuhan individu anggotanya, antara lain berupa kebutuhan: fisik, rasa aman (savety), hubungan sosial (social affiliation), 
pengakuan (esteem), pengembangan pengakuan (self actualization) (Elizabeth, 2017a). Diversifikasi pangan akan berjalan lancar bila dipadukan dengan pengembangan agroindustri berbahan baku produk hasil pertanian domestik (lokal), dan sebaiknya dibangun di daerah-daerah pedesaan. Dengan tambahan harapan bahwa strategi ini dapat menciptakan lapangan kerja bagi masyarakat desa, dan dapat mendorong pencapaian dan berkembangnya perekonomian di pedesaan.

\section{Kesimpulan dan Implikasi Kebijakan}

Untuk mencapai kedaulatan pangan, diperlukan strategi dalam upaya pemenuhan kebutuhan pangan yang beragam yang bahan bakunya berasal dari produk domestik, baik sebagai bahan diversifikasi pangan yang paling mendasar, maupun sebagai bahan baku usaha pengolahan. Strategi tersebut bertujuan sebagai upaya mengurangi dan memperkecil perolehan bahan baku yang berasal dari impor.

Aspek konsumsi (diversifikasi pangan) yang sangat erat dengan kepentingan nasional (pemerintah). Aspek produksi (diversifikasi tanaman pangan) yang sangat erat kaitannya dengan kepentingan petani dalam berusahatani, sebagai strategi dalam upaya pencapaian dan peningkatan pendapatan dan kesejahteraan petani, dimana keduanya dapat berjalan secara simultan.

Tujuan utama pemberantasan kemiskinan dan kelaparan yang sangat terkait dengan ketahanan pangan, karena keterkaitan tersebut merupakan suatu agenda yang tidak pernah berakhir (the unfinished agenda). Secara definisi ketahanan pangan merupakan terpenuhinya kebutuhan pangan bagi rumah tangga yang tercermin dari tersedianya pangan secara cukup baik dari segi jumlah dan mutunya.

Diperlukan strategi sebagai upaya pemantapan ketahanan pangan yang berkaitan erat dengan upaya peningkatan pendapatan skala rumah tangga. Tingkat pendapatan rumah tangga dapat mencerminkan dan menjadi salah satu faktor kunci bagi rumah tangga untuk menjadi salah satu ukuran kemampuan dalam mengakses konsumsi pangan yang dibutuhkan beserta keragamannya.

Perlunya dukungan kebijakan pemerintah yang lebih fokus dan berpihak untuk pencapaian dan pengembangan diversifikasi dan kedaulatan pangan, sangat diperlukan ketersediaan perangkat kebijakan yang 
memadai, teknologi dan informasi yang dibutuhkan, serta berfungsinya lembaga pendukung lainnya seperti: penyuluhan, pemasaran, dan sistem pendekatan instansi terkait. Diversifikasi pangan akan berjalan lancar bila dipadukan dengan pengembangan agroindustri berbahan baku produk hasil pertanian domestik (lokal) yang dibangun di pedesaan.

\section{DAFTAR PUSTAKA}

Astuti. 2012. bahan makanan sagu adalah hasil ekstraksi bagian inti batang pohon sagu. Di tepi-tepi pantai Sumatera Timur, Kalimantan, Sulawesi, 2 Nop 2012 di downlod tgl, 14 Nopember 2021

Balai Besar Industri Agro Bogor (BBIA. Bogor). 2014. Pengembangan Industri Agro di Indonesia. Makalah disampaikan pada Seminar Forum Komunikasi Kelitbangan (FKK) Kementan, Serpong, 14 Mei 2014.

Dewi, Febriantina danYusalina. 2011. Aplikasi Theory Of Planned Behavior pada Analisis Perilaku Konsumen Beras Organik di Kota Bogor. Prosiding Seminar Penelitian Unggulan Departemen Agribisnis. Bogor: IPB, Desember, 7-14, 2011

Elizabeth. R. 2020. Akselerasi Inovasi Teknologi Spesifik Lokasi Strategi Peningkatan Produksi Di Masa Pandemi Covid-19. Mimbar Agribisnis: Jurnal Pemikiran Masyarakat Ilmiah Berwawasan Agribisnis. Vol 1, No 2 (2020): Jan. 2020. Akreditasi Nomor 34/E/KPT/2018 at SINTA 4 (S4) rank. Accreditation is valid from December 10, 2018 to December
10, 2023.2 DOI: http://dx.doi.org/10.25157/ma.v5i2. 2411

Elizabeth. R. 2019. Peningkatan Dayasaing Tanaman Pangan Melalui Akselerasi Agroindustri Dan Pemberdayaan Kelembagaan Pertanian. Mimbar Agribisnis: Jurnal Pemikiran Masyarakat Ilmiah Berwawasan Agribisnis. Vol 5, No 2 (2019): Juli 2019. Akreditasi Nomor 34/E/KPT/2018 at SINTA 4 (S4) rank. Accreditation is valid from December 10, 2018 to December 10, 2023. DOI: http://dx.doi.org/10.25157/ma.v5i2. 2411

Elizabeth. R. 2017a. Akselerasi Pemberdayaan Dan Peningkatan Kompetensi Dalam Sistem Produksi Untuk Mengatasi Permasalahan Ekonomi Di Indonesia. Volume 2. Issue 1. June 2017. ISSN Cetak: 2528-5556. ISSN Online: 2528-6226.

Elizabeth. R. 2017. Revitalisasi Industri Produk Olahan Dan Pemberdayaan Lembaga Kemitraan Mendukung Peningkatan Pemasaran, Daya Saing Dan Pensejahteraan Petani Pisang. Journal of Agricultural Scienties. UNES. (Universitas Ekasakti). Padang Sumatera Barat. Volume 2. Issue 1. June 2017. ISSN Cetak: 2528-5556. ISSN Online: 2528-6226.

Elizabeth, R. 2016. Pemberdayaan Petani Dalam Pengelolaan Tanaman Dan Ternak Guna Meningkatkan Kesejahteraan Petani. Prosiding Seminar Nasional Agustus 2016. BPTP Sulawesi Utara. Manado. Badan Litbang Pertanian. Sekretaris Jenderal Pertanian. Kementerian Pertanian.

Elizabeth. R. 2015. Pencapaian Daya Saing Melalui Peningkatan 
Teknologi Pengolahan, Peningkatan Kelembagaan Dan Pemasaran Produk Pangan Olahan. PERHEPI. Tema: Indonesia Menuju Swasembada Pangan Dalam Tiga Tahun Kedepan: "Tinjauan Konseptual, Teoritis dan Empiris". Kendari, 9 Maret, 2015.

Elizabeth. R. 2014. Mewujudkan Kemandirian Dan Ketahanan Pangan Melalui Revitalisasi Dan Pengembangan Infrastruktur Pertanian. Konferensi Nasional XVII dan Kongres XVI PERHEPI. IPB International Convention Center (IICC). Bogor.

Fauzi Aziz. 2014. Hilirisasi Cermin Politik Industri. Bisnis Indonesia. http://www.neraca.co.id/bisnisindonesia. (6-6-2021)

Hadi P. 2014. Reformasi Kebijakan Penciptaan Nilai Tambah Produk Pertanian Indonesia. Reformasi Kebijakan Menuju Trasformasi Pembangunan Pertanian. Haryono (editor). Badan Litbang Pertanian.

Kaniasari, N. 2012. Meningkatkan Nilai Tambah dan Daya Saing Produk Pertanian.

Kementerian Keuangan Republik Indonesia. 2014. Laporan: Kajian Nilai Tambah Produk Pertanian. Laporan

Kementerian Koodinator Bidang Perekonomian. 2016. Outlook Ekonomi Indonesia 2017: Melanjutkan Reformasi: Menjaga Ketahanan dan Memacu Pertumbuhan Ekonomi. Jakarta, 10 November 2016.

Kusumawardani MH. 2012. Membuat Rantai Nilai Lebih Berpihak Pada Kaum Miskin: Buku Pegangan Bagi Praktisi Analisis Rantai Nilai. Australian Goverment(AU): Aciar.

Putra I K T E, I P G Sukaatmadja, N Ny K Yasa. 2016. Perilaku Konsumen Mengkonsumsi Beras Organik
Dikota Denpasar Berdasar Theory

Of Planned Behavior. E-Jurnal Ekonomi dan Bisnis Univ. Udayana 5.8 (2016):2609-2638. ISSN:23373067

Pribadu. N. 2014. Ketersediaan dan Ketahanan Pangan. Kemandirian pangan menuju ketahanan pangan berkelanjutan . bekerjasama Badan Ketahanan Pangan Ddepertemen Pertanian dengan Ekonomi Vol. 24/Juni 2014.

Rachmat, M. R. Elizabeth. Supadi. H. Supriyadi. P. U. Hadi. S. Nuryanti. 2012. Studi Kebutuhan Pengembangan Produk Olahan Pertanian Dalam Rangka Liberalisasi Perdagangan. LHP. PSEKP. Bogor. Badan Litbang Pertanian. Kementerian Pertanian. Jakarta.

Sulistyana P, J H Mulyo, Jamhari. 2014. Konsumsi Beras Organik Tingkat Rumah Tangga. Agro

Susilawati S H,. H P Saliem. E. Ariningsih. R. Elizabeth. C R Addawiyah. 2018. Strategi Antisipatif Pengelolaan Surplus Produksi Padi Dan Jagung. LHP. PSEKP. Sek Jen. Kementan.

Tjeppy D.Sudjana. 2011. Peningkatan Konsumsi Daging Ruminanisa Kecil dalam Rangka Diversifikasi Pangan daging Mendukung PSDSK 2014. Prosing Workshop Nasional Diversihikasi Pangan Daging Ruminansia Kecil, Psulitbang Peternakan bekerjasama dengan Pusat penelitain Perkebunan Jakaera, 15 oktober 2011, hal 1726.

Wijaya, Tony. 2014. Nilai dan Pengetahuan sebagai Prediktor Intensi Membeli Makanan Organik. Jurnal Manajemen dan Kewirausahaan, 16:69-82.

Wijaya, Tony. 2013. Anteseden Perilaku beli Produk Ramah Lingkungan : 
Studi Perilaku Konsumen Makanan Organik. Jurnal Ekonomi dan Bisnis, 7(3):149-161.

YLKI., 2012, Survei Konsumen Organik Indonesia, (Online), (www.organikindonesia.org) Download Juni 2021.

Yulvianus Harjono 2012. Bandar lampung, Kompas.com-Kompas Hariadi sapto lustrasi: Pembukaan 1,2 juta hektar hutan di Papua untuk kepentingan MIFEE bisa mengancam hilangnya dusun sagu yang sangat pokok bagi warga Papua. Senin, 8 Oktober 2012 18:56 WIB. 